\title{
Influence of Method and Application Time of Nitrogen on Pest Incidence of Sorghum [Sorghum bicolor (L.) Moench] Genotypes
}

\author{
Neelesh Raypuriya ${ }^{1 *}$, R. K. Choudhary ${ }^{1}$, P. Swathi ${ }^{1}$ and Sunil Prajapati ${ }^{2}$ \\ ${ }^{1}$ Dept. of Entomology, College of Agriculture Indore, Rajmata Vijayaraje Scindia Krishi Vishwa Vidyalaya, Gwalior, \\ M.P. (452 001), India \\ ${ }^{2}$ Dept. of Horticulture, College of Agriculture Jabalpur, Jawaharlal Nehru Krishi Vishwa Vidyalaya, Jabalpur, M.P. (482 004), India
}

\section{Corresponding Author}

Neelesh Raypuriya

e-mail: neeleshrai87@gmail.com

\author{
Article History \\ Manuscript No. AR1735 \\ Received in $18^{\text {th }}$ November, 2016 \\ Received in revised form $17^{\text {th }}$ April, 2017 \\ Accepted in final form $7^{\text {th }}$ June, 2017
}

\begin{abstract}
An experiment was conducted under open field condition in the month of June to December in the year of 2013 at College of Agriculture, Indore, R.V.S.K.V.V. (M.P.), India. Nitrogen application time and cultivars were significantly effective but their interaction was nonsignificantly effective for incidence of insect pest (exception of ear head bug), whereas both factor and interaction were significantly effective to growth parameter. CSV20 was recorded with significantly lowest incidence of pests and maximum for growth parameters in comparison to $\mathrm{CSH} 16$ in nitrogen application time treatment $\mathrm{N}_{1}: 50 \%$ at sowing $+50 \%$ at 30 DAS maximum incidence of Shoot fly $(57.87 \%$ and $64.39 \%$ ) at 14 and 21 days, while minimum in stem borer dead hearts (41.15\%) at $45 \mathrm{DAE}$, Ear head pests (3.75 bug \& 3.0 worm) at milk stage, $\mathrm{N}_{2}: 50 \%$ at sowing $+25 \%$ at $30 \mathrm{DAS}+25 \%$ at boot leaf stage was found highest height of plant $(182.33 \mathrm{~cm}),. \mathrm{N}_{3}: 25 \%$ at sowing $+50 \%$ at $30 \mathrm{DAS}+25 \%$ at BLS has been recorded higher stem borer dead hearts (51.42\%), $\mathrm{N}_{4}: 25 \%$ at sowing $+50 \%$ at $30 \mathrm{DAS}+15 \%$ at $\mathrm{BLS}+10 \%$ at grain filling stage reported maximum ear head pests (6.78\% and $4.27 \%)$, treatment $\mathrm{N}_{5}: 25 \%$ at sowing $+45 \%$ at $30 \mathrm{DAS}+5 \%$ foliar spray at $45 \mathrm{DAS}+15 \% \mathrm{BLS}+10 \% \mathrm{GFS})$ recorded minimum incidence of shoot fly (43.85\% and $51.12 \%)$. Among the treatment maximum number of grains ear head ${ }^{-1}$ was recorded in the treatment $\mathrm{N}_{4},(2369.33)$ at GFS and N5 (2111.17) at GFS with and higher yield plot ${ }^{-1}$ and stover yield was recorded in the treatment $\mathrm{N}_{5}(2.79 \mathrm{~kg}$ and $2.88 \mathrm{~kg})$ respectively.
\end{abstract}

Keywords: Sorghum, nitrogen-fertilizers, interaction, insect pest

\section{Introduction}

Sorghum [Sorghum bicolor (L). Moench] is well adapted to sub-tropical and temperate regions of the world and used in different ways in many countries. Sorghum is consumed food and feed and used for sugar, ethanol and paper pulp production. Sorghum is grown in an area of 61.80 mha with a production of $52.80 \mathrm{mt}$ and productivity of $854.4 \mathrm{~kg} \mathrm{ha}^{-1}$ in India (Anonymous, 2013-14). In Madhya Pradesh, sorghum crop is grown mainly in Kharif and covers an area of 307.5 ha and production 542.9 tonnes with productivity of 1809 $\mathrm{kg} \mathrm{ha}^{-1}$ respectively (Anonymous, 2009-10). Sorghum mainly cultivated in Malwa fallowed by Jhabua, Nimar, Gird and Satpura plateau of Madhya Pradseh. Selection of resistant or tolerant varieties is a very important factor the diversity and intensity of pests in a particular place. Plant Growth Promoting Rhizobacteria (PGPR) used in the production of biofertilizers is an effective and economic means to control plant diseases (Ameer Basha et al., 2013). Plants have their own sophisticated mechanisms to protect from the pest attack. Majority of the traditional varieties are resistant to many pests. Application of nitrogen to the crop increased infestation and damage by headbugs as was the case for shootfly. The importance of $\mathrm{N}$ fertilizers to increased Sorghum production was also demonstrated with a caution to limit application rate to below $50 \mathrm{~kg}$ to minimize adverse effects of insect pests and maintain or improve grain quality (Tanzubil Paul B., 2014). Nitrogen, phosphorus and potassium are fundamental nutrients for plant growth and development which play a basic role in metabolism and energy production in plants and significantly enhance the grain yield. Considering in the light of above facts the following studies have been under taken to confirm the findings in this zone. The aim of this research is to study the effect of nitrogen levels, plant density and its interaction with sorghum insect pests, nitrogen fertilizer on quantity and quality of sorghum grain.

\section{Materials and Methods}

\subsection{Study sites}

An experiment was conducted under open field condition in the month of June to December in the year of 2013 at College 
of Agriculture, Indore, R.V.S.K.V.V. (M.P.). The soil of this region medium black cotton soil, Indore is situated in the "Malwa Plateau" which is Agro-climatic zone of Madhya Pradesh. Geographical parameters at Indore: Latitude of $22^{\circ} 43^{\prime} \mathrm{N}$, Longitude of $75^{\circ} 56^{\prime} \mathrm{E}$, Altitude of $555.7 \mathrm{~m} \mathrm{MSL}$. The climate of this region is semi-arid, sub-tropical having mid-winter and summer with uncertain winter rains. The rainfall occurs mostly from mid-June to the end of September.

\subsection{Method of data collection}

In order to explore the effect of various five Nitrogen fertilizer doses including $\left(\mathrm{T}_{1}\right) \mathrm{N}_{1}: 50 \%$ at sowing+50\% at 30 Day after sowing (DAS), $\left(\mathrm{T}_{2}\right) \mathrm{N}_{2}: 50 \%$ at sowing $+25 \%$ at $30 \mathrm{DAS}+25 \%$ at Boot leaf stage (BLS), $\left(\mathrm{T}_{3}\right) \mathrm{N}_{3}: 25 \%$ at sowing+50\% at 30 DAS $+25 \%$ at $B L S,\left(T_{4}\right) N_{4}: 25 \%$ at sowing $+50 \%$ at $30 \mathrm{DAS}+15 \%$ at BLS+10\% at Grain filling stage (GFS), $\left(\mathrm{T}_{5}\right) \mathrm{N}_{5}: 25 \%$ at sowing $+45 \%$ at $30 \mathrm{DAS}+5 \%$ foliar spray at $45 \mathrm{DAS}+15 \%$ BLS+10\% GFS) and two cultivars CSV20, CSH16, were assessed in a Factorial Randomized Block Design (FRBD) with three replications. Seeds were planted in rows $0.45 \mathrm{~m}$., plants 0.12 $\mathrm{m}$. Nitrogen fertilizer were applied in 4 stages: pre-sowing, 30 day after sowing, boot leaf stage, grain filling stage and observed the major insect pests of sorghum viz., shoot fly, stem borer, ear head bug and worm. All the data obtained with regard to the pests' incidence, growth, yield and yield attributing were analyzed statistically using the analysis of variance of Fisher and Yates (1963).

\section{Results and Discussion}

The nitrogen application time and cultivars were significantly effective but their interaction of both the factors $(\mathrm{N} \times \mathrm{C})$ was non-significantly effective for Incidence of shoot fly, stem borer and ear head worm. However, cultivar and interaction were not significantly effective but nitrogen application was significantly effective for incidence of ear head bug. Cultivar CSV20 has been recorded to be significantly for minimum shoot fly, stem borer and ear head pest incidence in comparison to CSH16.

\subsection{Shoot fly (Atherigona soccata Rondani)dead heart percent}

The data presented in (Table 1 ) the nitrogen application time $\mathrm{N}_{1}$ (50\% at sowing+50\% at 30 DAS) was found maximum dead hearts (57.87\% and 64.39\%) at both stage (14 and 21 DAE) followed by $\mathrm{N}_{2}$ (50\% at sowing $+25 \%$ at $30 \mathrm{DAS}+25 \%$ at BLS) and $\mathrm{N}_{3}(25 \%$ at sowing $+50 \%$ at $30 \mathrm{DAS}+25 \%$ at BLS) $)$ with 52.12 and $51.25 \%$ dead hearts at 14 DAE and 59.46 and $59.21 \%$ dead hearts at 21 DAE. However minimum incidence of shoot fly was reported in $\mathrm{N}_{5}$ (25\% at sowing+45\% at $30 \mathrm{DAS}+5 \%$ foliar spray at 45 DAS+15\% BLS+10\%GFS) with 43.85 and $51.12 \%$ at 14 and 21 DAE. Similar findings are reported by Pandey

Table 1: Impact of application time of nitrogen and cultivar on incidence of shoofly dead hearts \%

\begin{tabular}{|c|c|c|c|c|c|c|}
\hline \multirow{2}{*}{$\begin{array}{l}\text { Application } \\
\text { time of } \mathrm{N}_{2}\end{array}$} & \multicolumn{3}{|c|}{ Shoot Fly 14 DAE } & \multicolumn{3}{|c|}{ Shoot Fly $21 \mathrm{DAE}$} \\
\hline & CSV20 & $\mathrm{CSH} 16$ & Mean & CSV20 & $\mathrm{CSH} 16$ & Mean \\
\hline $\mathrm{N}_{1}$ & $53.89(47.23)$ & $61.84(51.87)$ & $57.87(49.55)$ & $58.43(49.86)$ & $70.35(57.03)$ & $64.39(53.44)$ \\
\hline $\mathrm{N}_{2}$ & 49.57(44.75) & $54.67(47.68)$ & $52.12(46.22)$ & $57.58(49.36)$ & $61.35(51.56)$ & $59.46(50.46)$ \\
\hline $\mathrm{N}_{3}$ & $48.95(44.40)$ & $53.54(44.40)$ & $51.25(45.72)$ & $57.58(49.37)$ & $60.84(51.27)$ & $59.21(50.32)$ \\
\hline $\mathrm{N}_{4}$ & $45.78(42.58)$ & $53.06(46.75)$ & 49.42(44.67) & $52.30(46.32)$ & $60.82(51.26)$ & $56.56(48.79)$ \\
\hline $\mathrm{N}_{5}$ & $42.31(40.58)$ & $45.39(42.35)$ & $43.85(41.46)$ & $48.56(44.17)$ & $53.68(47.11)$ & $51.12(45.64)$ \\
\hline \multirow[t]{2}{*}{ Mean } & $48.10(43.91)$ & $53.70(47.14)$ & $50.90(45.52)$ & $54.89(47.82)$ & $61.41(51.65)$ & $58.15(49.73)$ \\
\hline & V & $\mathrm{N}$ & $\mathrm{V} \times \mathrm{N}$ & V & $\mathrm{N}$ & $\mathrm{V} \times \mathrm{N}$ \\
\hline SEm \pm & 0.62 & 0.54 & NS & 0.60 & 0.52 & NS \\
\hline $\mathrm{CD}(P<0.05)$ & 1.84 & 1.59 & NS & 1.79 & 1.55 & NS \\
\hline
\end{tabular}

NS: Non-Significant, V: Variety/Cultivar, N: Nitrogen Application Time, $\mathrm{V} \times \mathrm{N}$ : Interaction Values in parenthesis are transformed (arc sin transformation) value

(2003); Bortoliet al. (2005); Tanzubil et al. (2006); Obonyo et al. (2008); Sarao and Mahal (2008); Karikari et al. (2013).

3.2. Percent leaf injury, dead hearts and stem tunneling due to stem borer

The data presented in (Table 2) the minimum leaf injury $(3.28 \%)$ was reported in the nitrogen application time $\mathrm{N}_{5}(25 \%$ at sowing $+45 \%$ at $30 \mathrm{DAS}+5 \% \mathrm{FS}$ at $45 \mathrm{DAS}+15 \% \mathrm{BLS}+10 \% \mathrm{GFS})$ which was at par with $\mathrm{N}_{4}(25 \%$ at sowing $+50 \%$ at $30 \mathrm{DAS}+15 \%$ at BLS+10\% at GFS) and $\mathrm{N}_{3}(25 \%$ at sowing $+50 \%$ at $30 \mathrm{DAS}+25 \%$ at BLS) with 3.12 and $3.68 \%$ leaf injury respectively, while maximum leaf injury $(5.05 \%)$ was recorded in $N_{1}(50 \%$ at sowing $+50 \%$ at 30 DAS).The lowest incidence of stem borer (dead hearts and stem tunneling) has been recorded in $\mathrm{N}_{1}$, $50 \%$ at sowing+50\% at 30 DAS (41.15 and $4.70 \%$ ) followed by $\mathrm{N}_{5}, 25 \%$ at sowing $+45 \%$ at $30 \mathrm{DAS}+5 \% \mathrm{FS}$ at $45 \mathrm{DAS}+15 \%$ BLS+10\% GFS (43.05 and 5.13\%) respectively, however $\mathrm{N}_{3}$, $25 \%$ at sowing $+50 \%$ at $30 \mathrm{DAS}+25 \%$ at BLS) was found to be maximum (51.42 and 5.95\%). The present funding supported by Tanzubil et al.(2006); Dashet al. (2007); Sarao and Mahal (2008); Bhavani et al. (2012); Karikari et al. (2013).

3.3. Ear head bug (Calocoris angustatus Leth.) and worms (Cryptoblabus gnidiella Mab.) 


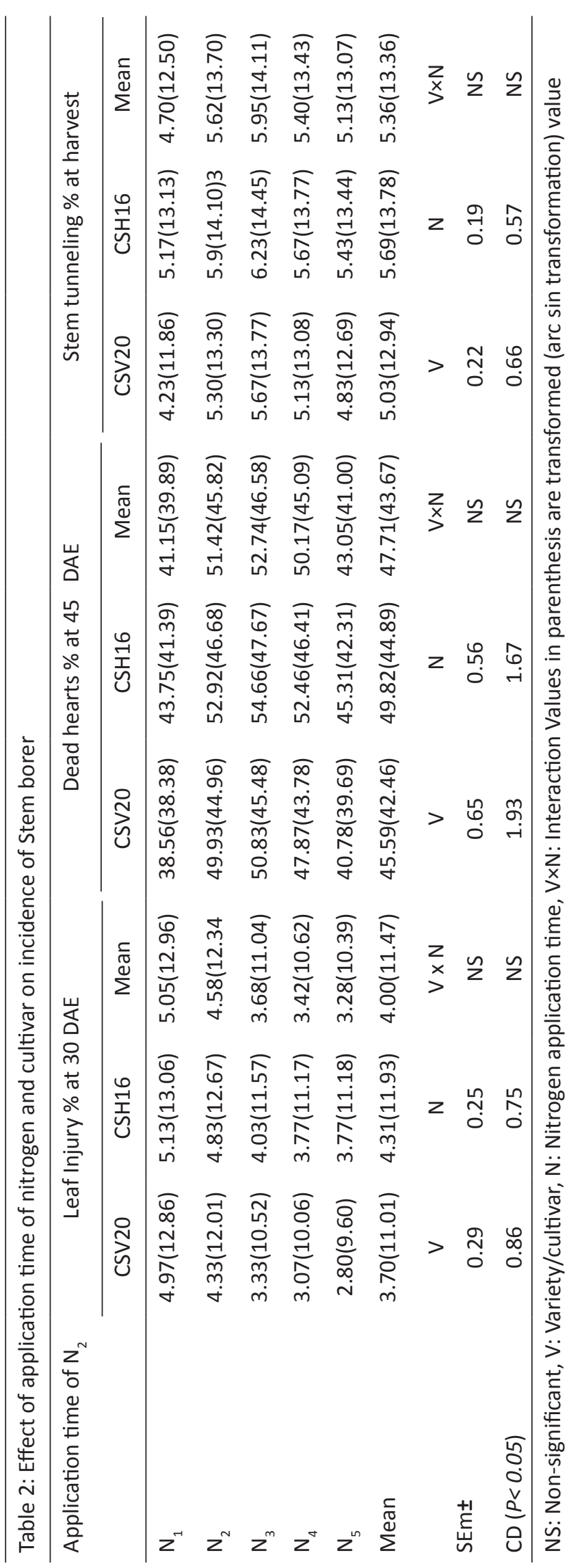

The data presented in (Table 3 ) the application time of nitrogen minimum ear head pest (bug and worm 3 plants $^{-1}$ ) has been counted in $N_{1}, 50 \%$ at sowing $+50 \%$ at 30 DAS (3.75 bug and 3.00 worm) followed by $\mathrm{N}_{2}, 50 \%$ at sowing $+25 \%$ at 30 DAS $+25 \%$ at $\mathrm{BLS}$ and $\mathrm{N}_{3}, 25 \%$ at sowing $+50 \%$ at $30 \mathrm{DAS}+25 \%$ at BLS (4.42 and 5.20 bug and 3.27 and 3.75 worm), while in $\mathrm{N}_{4^{\prime}}$ $25 \%$ at sowing $+50 \%$ at $30 \mathrm{DAS}+15 \%$ at $\mathrm{BLS}+10 \%$ at GFS was found to be maximum ( 6.78 bug and 4.27 worm). The present funding are partially supported by Bortoliet al. (2005); Tanzubil et al. (2006); Randhawaet al. (2014); Karikari et al. (2013).

\subsection{Expression of growth parameters}

The data presented in (Table 4) among the treatment in the application time of Nitrogen the maximum higher plant population was found in $\mathrm{N}_{1}, 50 \%$ at sowing $+50 \%$ at 30 DAS (86.67) closely followed by $\mathrm{N}_{2}, 50 \%$ at sowing $+25 \%$ at 30 DAS $+25 \%$ at BLS (80.83), while minimum plant population was recorded in $\mathrm{N}_{3}, 25 \%$ at sowing $+50 \%$ at $30 \mathrm{DAS}+25 \%$ at BLS (75.33). Among the treatment, the lowest days for $50 \%$ flowering was noticed in $\mathrm{N}_{3}, 25 \%$ at sowing $+50 \%$ at 30 DAS $+25 \%$ at BLS (96.00 days), closely followed by $\mathrm{N}_{2}, 50 \%$ at sowing $+25 \%$ at 30 DAS $+25 \%$ at BLS ( 96.50 days), while $\mathrm{N}_{4}, 25 \%$ at sowing $+50 \%$ at $30 \mathrm{DAS}+15 \%$ at $\mathrm{BLS}+10 \%$ at GFS was found to be maximum (100.50) days to $50 \%$ flowering. Among the treatment of $\mathrm{N}_{1}, 50 \%$ at sowing $+50 \%$ at $30 \mathrm{DAS}$ was recorded minimum ( 129 days) days to $50 \%$ maturity closely followed by $\mathrm{N}_{2}, 50 \%$ at sowing $+25 \%$ at $30 \mathrm{DAS}+25 \%$ at BLS (129.67 days). The maximum ( 131.00 days) days to $50 \%$ to maturity was recorded in $\mathrm{N}_{3}, 25 \%$ at sowing $+50 \%$ at $30 \mathrm{DAS}+25 \%$ at BLS. Among the treatment highest height 182.3 was recorded when the Nitrogen application time apply $\mathrm{N}_{2},(50 \%$ at sowing $+25 \%$ at $30 \mathrm{DAS}+25 \%$ at BLS) followed by $\mathrm{N}_{5}, 25 \%$ at sowing $+45 \%$ at $30 \mathrm{DAS}+5 \% \mathrm{FS}$ at $45 \mathrm{DAS}+15 \% \mathrm{BLS}+10 \% \mathrm{GFS}(178.67 \mathrm{~cm})$. The present funding is partially supported by Sing et al. (2007a, b); Ananda and Patil (2007).

\subsection{Expression of yield parameters}

The data presented in (Table 5), the impact of cultivar to obtain yield per five plants of $\mathrm{CSH} 16$ was significantly superior to CSV20, while the performance of cultivar to yield kg plot ${ }^{-1}$ and grain ear head ${ }^{-1}$, cultivar CSV20 was reported significantly superior than $\mathrm{CSH} 16$. Among the treatment maximum number of grains per ear head was recorded in the treatment $\mathrm{N}_{4}, 25 \%$ at sowing $+50 \%$ at $30 \mathrm{DAS}+15 \%$ at BLS $+10 \%$ at GFS $(2369.33$ grain) followed by $\mathrm{N}_{3}, 25 \%$ at sowing $+50 \%$ at $30 \mathrm{DAS}+25 \%$ at BLS and $\mathrm{N}_{5}, 25 \%$ at sowing $+45 \%$ at $30 \mathrm{DAS}+5 \% \mathrm{FS}$ at 45 DAS+15\% BLS+10\% GFS with 2359.00 and 2111.17 grain earhead $^{-1}$, while minimum number of grain (1571.50) was recorded in $\mathrm{N}_{2^{\prime}}$ (50\% at sowing+25\% at $30 \mathrm{DAS}+25 \%$ at BLS). Among the treatment maximum yield $(221.70 \mathrm{~g})$ per five plant was recorded in $\mathrm{N}_{2}, 50 \%$ at sowing $+25 \%$ at $30 \mathrm{DAS}+25 \%$ at BLS followed by $\mathrm{N}_{5}, 25 \%$ at sowing $+45 \%$ at $30 \mathrm{DAS}+5 \%$ FS at $45 \mathrm{DAS}+15 \% \mathrm{BLS}+10 \% \mathrm{GFS}(202.83 \mathrm{~g})$ and $\mathrm{N}_{4}, 25 \%$ at sowing $+50 \%$ at $30 \mathrm{DAS}+15 \%$ at BLS+10\% at GFS (199.68 g), while minimum yield per five plant (153.87 g) was recorded in $\mathrm{N}_{1}, 50 \%$ at sowing+50\% at $30 \mathrm{DAS}$. Among the treatment higher yield per plot was recorded in the treatment $\mathrm{N}_{5}, 25 \%$ 


\begin{tabular}{|c|c|c|c|c|c|c|}
\hline \multirow{2}{*}{$\begin{array}{l}\text { Application } \\
\text { time of } \mathrm{N}_{2}\end{array}$} & \multicolumn{3}{|c|}{ Ear head bug } & \multicolumn{3}{|c|}{ Ear head worm } \\
\hline & CSV20 & $\mathrm{CSH} 16$ & Mean & CSV20 & $\mathrm{CSH} 16$ & Mean \\
\hline $\mathrm{N}_{1}$ & $3.70(11.08)$ & $3.80(11.22)$ & $3.75(11.15)$ & $2.67(9.39)$ & $3.33(10.52)$ & $3.00(9.95)$ \\
\hline $\mathrm{N}_{2}$ & $4.43(12.15)$ & $4.40(12.11)$ & $4.42(12.13)$ & $2.83(9.66)$ & $3.70(11.08)$ & $3.27(10.37)$ \\
\hline $\mathrm{N}_{3}$ & $5.03(12.96)$ & $5.37(13.39)$ & $5.20(13.18)$ & $3.43(10.67)$ & $4.07(11.62)$ & $3.75(11.15)$ \\
\hline $\mathrm{N}_{4}$ & $6.80(15.11)$ & $6.77(15.06)$ & $6.78(15.09)$ & $4.27(11.76)$ & $4.87(12.73)$ & $4.57(12.25)$ \\
\hline $\mathrm{N}_{5}$ & $6.10(14.29)$ & $6.43(14.69)$ & $6.27(14.49)$ & $3.80(11.23)$ & $4.73(12.55)$ & $4.27(11.12)$ \\
\hline \multirow[t]{2}{*}{ Mean } & $5.21(13.12)$ & $5.35(13.30)$ & $5.28(13.21)$ & $3.40(10.54)$ & $4.14(11.70)$ & $3.77(11.12)$ \\
\hline & V & $\mathrm{N}$ & $\mathrm{V} \times \mathrm{N}$ & V & $\mathrm{N}$ & $\mathrm{V} \times \mathrm{N}$ \\
\hline SEm \pm & NS & 0.16 & NS & 0.35 & 0.30 & NS \\
\hline $\mathrm{CD}(p<0.05)$ & NS & 0.47 & NS & 1.04 & 0.90 & NS \\
\hline
\end{tabular}

NS: Non-significant; V: Variety/cultivar; N: Nitrogen application time; $\mathrm{V} \times \mathrm{N}$ : Interaction values in parenthesis are transformed (square root transformation) value

\begin{tabular}{|c|c|c|c|c|c|c|c|c|c|c|c|c|}
\hline \multirow{2}{*}{$\begin{array}{l}\text { Application } \\
\text { time of } \mathrm{N}_{2}\end{array}$} & \multicolumn{3}{|c|}{ Plant population } & \multicolumn{3}{|c|}{ Days to $50 \%$ flowering } & \multicolumn{3}{|c|}{ Days to $50 \%$ maturity } & \multicolumn{3}{|c|}{ Plant height $(\mathrm{cm})$} \\
\hline & CSV20 & $\mathrm{CSH} 16$ & Mean & CSV20 & $\mathrm{CSH} 16$ & MEAN & CSV20 & $\mathrm{CSH} 16$ & MEAN & CSV20 & $\mathrm{CSH} 16$ & Mean \\
\hline $\mathrm{N}_{1}$ & 104.00 & 69.33 & 86.67 & 98.00 & 102.33 & 100.17 & 130.00 & 128.00 & 129.00 & 168.33 & 162.00 & 165.17 \\
\hline $\mathrm{N}_{2}$ & 94.33 & 67.33 & 80.83 & 95.00 & 98.00 & 96.50 & 128.00 & 131.33 & 129.67 & 185.00 & 179.67 & 182.33 \\
\hline $\mathrm{N}_{3}$ & 84.00 & 66.67 & 75.33 & 93.33 & 98.67 & 96.00 & 129.33 & 132.67 & 131.00 & 173.33 & 182.00 & 177.67 \\
\hline $\mathrm{N}_{4}$ & 85.33 & 75.00 & 80.17 & 100.67 & 100.33 & 100.50 & 130.67 & 129.67 & 130.17 & 172.00 & 166.33 & 169.17 \\
\hline $\mathrm{N}_{5}$ & 81.67 & 78.33 & 80.00 & 98.33 & 102.33 & 100.33 & 130.67 & 131.33 & 131.00 & 170.00 & 187.33 & 178.67 \\
\hline \multirow[t]{2}{*}{ Mean } & 89.87 & 71.33 & 80.60 & 97.07 & 100.33 & 98.70 & 129.73 & 130.60 & 130.17 & 173.73 & 175.47 & 174.60 \\
\hline & v & N & $\mathrm{V} \times \mathrm{N}$ & V & $\mathrm{N}$ & $\mathrm{V} \times \mathrm{N}$ & V & $\mathrm{N}$ & $\mathrm{V} \times \mathrm{N}$ & V & $N$ & $V \times N$ \\
\hline SEm \pm & 1.166 & 1.010 & 2.020 & 0.313 & 0.271 & 0.542 & 0.370 & 0.321 & 0.641 & 0.415 & 0.360 & 0.719 \\
\hline $\mathrm{CD}(p<0.05)$ & 3.465 & 3.000 & 6.001 & 0.930 & 0.805 & 1.611 & 1.100 & 0.953 & 1.905 & 1.234 & 1.069 & 2.137 \\
\hline
\end{tabular}

NS: Non- Significant, V: Variety/cultivar, N: Nitrogen application time, V×N: Interaction

Table 5: Effect of application time or nitrogen and cultivar on yield attributes

\begin{tabular}{|c|c|c|c|c|c|c|c|c|c|}
\hline \multirow{2}{*}{$\begin{array}{l}\text { Application time of } \\
\mathrm{N}_{2}\end{array}$} & \multicolumn{3}{|c|}{ No. of grain earhead ${ }^{-1}$} & \multicolumn{3}{|c|}{ Grain yield plot ${ }^{-1}(\mathrm{~kg})$} & \multicolumn{3}{|c|}{ Stover yield $(\mathrm{kg})$ net plot ${ }^{-1}$} \\
\hline & CSV20 & $\mathrm{CSH} 16$ & Mean & CSV20 & $\mathrm{CSH} 16$ & Mean & CSV20 & $\mathrm{CSH} 16$ & Mean \\
\hline $\mathrm{N}_{1}$ & 1981.00 & 1680.00 & 1830.50 & 2.82 & 1.89 & 2.36 & 2.98 & 1.96 & 2.47 \\
\hline $\mathrm{N}_{2}$ & 1615.00 & 1528.00 & 1571.50 & 3.00 & 2.30 & 2.65 & 3.10 & 2.53 & 2.81 \\
\hline $\mathrm{N}_{3}$ & 2338.00 & 2380.00 & 2359.00 & 2.54 & 2.37 & 2.45 & 2.91 & 2.11 & 2.51 \\
\hline $\mathrm{N}_{4}$ & 2419.00 & 2319.67 & 2369.33 & 2.83 & 2.71 & 2.77 & 2.92 & 2.43 & 2.67 \\
\hline $\mathrm{N}_{5}$ & 2223.67 & 1998.67 & 2111.17 & 2.79 & 2.78 & 2.79 & 2.82 & 2.94 & 2.88 \\
\hline \multirow[t]{2}{*}{ Mean } & 2115.33 & 1981.27 & 2048.30 & 2.80 & 2.41 & 2.60 & 2.94 & 2.39 & 2.67 \\
\hline & V & $\mathrm{N}$ & $\mathrm{V} \times \mathrm{N}$ & V & $\mathrm{N}$ & $V \times N$ & V & $\mathrm{N}$ & $\mathrm{V} \times \mathrm{N}$ \\
\hline SEm \pm & NS & 92.383 & NS & 0.058 & 0.050 & 0.101 & 0.072 & 0.063 & 0.125 \\
\hline $\mathrm{CD}(p<0.05)$ & NS & 274.494 & NS & 0.173 & 0.150 & 0.300 & 0.214 & 0.186 & 0.371 \\
\hline
\end{tabular}

NS: Non-Significant; V: Variety/cultivar; N: Nitrogen application time; V×N: Interaction 
at sowing $+45 \%$ at $30 \mathrm{DAS}+5 \% \mathrm{FS}$ at $45 \mathrm{DAS}+15 \% \mathrm{BLS}+10 \% \mathrm{GFS}$ $(2.79 \mathrm{~kg})$ followed by $\mathrm{N}_{4}, 25 \%$ at sowing $+50 \%$ at $30 \mathrm{DAS}+15 \%$ at BLS+10\% at GFS ( $2.77 \mathrm{~kg})$ and $\mathrm{N}_{2}, 50 \%$ at sowing $+25 \%$ at 30 DAS+25\% at BLS (2.65 kg). The minimum (2.36 kg) yield plot ${ }^{-1}$ was recorded when treated by $\mathrm{N}_{1}, 50 \%$ at sowing $+50 \%$ at 30 DAS. The performance of cultivar to stover yield CSV-20 (2.94 $\mathrm{kg}$ ) was significantly superior compared to CSH $16(2.39 \mathrm{~kg}$ plot $\left.^{-1}\right)$. The time of nitrogen application and interaction were also significant to stover yield. Among the application time of nitrogen higher stover yield ( $2.88 \mathrm{~kg}$ ) was reported in $\mathrm{N}_{5}, 25 \%$ at sowing $+45 \%$ at $30 \mathrm{DAS}+5 \% \mathrm{FS}$ at $45 \mathrm{DAS}+15 \% \mathrm{BLS}+10 \% \mathrm{GFS}$ followed by $\mathrm{N}_{2}, 50 \%$ at sowing $+25 \%$ at $30 \mathrm{DAS}+25 \%$ at BLS $(2.81 \mathrm{~kg})$. The present funding is supported by Obonyo et al. (2008); Rashid et al. (2008); Yusefzadeh et al. (2013).

\section{Conclusion}

CSV20 estimated minimum incidence of stem borer dead hearts and ear head pest treatment with $\mathrm{N}_{1}$ and maximum plant height and yield with $\mathrm{N}_{2}$ in comparison to $\mathrm{CSH} 16$ while CSH 16 produced maximum days to $50 \%$ maturity treatment with $\mathrm{N}_{3}$ and $50 \%$ floweringtreatment with $\mathrm{N}_{4}$, while maximum grain yield plot ${ }^{-1}$ and stover yield treatment with $\mathrm{N}_{5}$ as compared to CSV 20.

\section{Acknowledgement}

The author highly acknowledges to Director Research Services, Director Extension Services, Director Instruction, Head of Department Agriculture Entomology and Project In-Charge, All India Co-Ordinated Sorghum Improvement Project, College of Agriculture, Indore, RVSKVV, Gwalior (Madhya Pradesh) to provide facility for investigate this work successfully.

\section{References}

Ameer Basha, S., Raghavendra, G., Nagesh Kumar, M.V., Dharma Reddy, K., Sudhakar, R., 2013. Performance of Native Fluorescent Pseudomonas on in vitro Seed Germination and Seedling Vigour of Sorghum bicolor (L.) Moench.International Journal of Bio-resource and Stress Management 4(4), 87-91.

Ananda, N., Patil, B.N., 2007. Quality parameters of durum wheat (Triticum durum Desf.) as influenced by zinc, iron and time of nitrogen application. Research on Crops 8(3), 520-525.

Anonymous, 2009-10. Commissioner Land Records and Settlement, Gwalior, Madhya Pradesh (India) available from http://landrecords.mp.gov.in/ 2009-10.

Anonymous, 2013-14. FAO Statistical Yearbook 2013, Food and Agriculture Organization of The United Nation available from http://FAOSTAT 2013.

Bhavani, B., Reddy, K.D., Rao, N.V., Lakshmi, M.B., Reddy, D.J., 2012. Effect of nitrogen, phosphorus, potassium, total sugar and moisture content on the incidence of the early shoot borer, Chilo infuscatellus Snellen in sugarcane. International Sugar Journal 114(1366), 738-743.

Bortoli, S.A., de Doria, H.O.S., Albergaria, N.M.M.S.,
Botti, M.V., 2005. Biological aspects and damage of Diatraeasaccharalis (Lepidoptera: Pyralidae) in sorghum, under different doses of nitrogen and potassium. Ciencia e Agrotecnologia 29(2), 267-273.

Dash, D., Senapati, B., Rath, L.K., 2007. Influence of rice varieties and plant nutrients on the incidence of the yellow stem borer, Scirpophagaincertulas (Walker), under protected conditions. Pest Management and Economic Zoology 15(1), 57-62.

Fisher and Yates, 1963. Statistical tables for biological, agricultural and medical research ( $6^{\text {th }}$ Edn.) Oliver \& Boyd, Edinburgh and London. X,146 P. Preis $42 \mathrm{~s}$ net.

Karikari, A.S., Atokple, I.D.K., Buah, S.S., Abdulai, A.L., Asungre, P., 2013. Effect of fertilizer rates on the incidence of insect pests of Sorghum bicolor (L) Moench in the northern region of Ghana. Fourth International Scientific Symposium "Agrosym ", Jahorina, Bosnia and Herzegovina, 3-6 October, 578-583.

Obonyo, D.N., Ogola, J.B.O., Kamau, A.W., 2008. Effects of time of planting, fertilizer and insecticide on sorghum shoot fly, Atherigona soccata (Diptera: Muscidae), on two varieties of sorghum. African Entomology 16(2), 185-195.

Pandey, S.K., 2003. Influence of different levels of nitrogen on the incidence of major insect pests of rice. Journal of Entomological Research 27(4), 341-345.

Randhawa, H.S., Aulakh, S.S., 2014. Effect of nitrogen levels and varieties on the incidence of leaf folder and stem borer of basmati rice. Indian Journal of Entomology 76(1), 82-83.

Rashid, A., Khan, R.U., Ullah, H., 2008. Influence of nitrogen levels and application methods on yield and quality of sorghum. Pedosphere 18(2), 236-241.

Sarao, P.S., Mahal, M.S., 2008. Incidence of insect pests at different levels of nitrogen application in rice. Journal of Insect Science (Ludhiana) 21(2), 127-132.

Singh P., Sumeriya, H.K., Sharma, V., 2007b. Productivity and profitability of forage sorghum genotypes as influenced by various nitrogen levels. Research on Crops 8(2), 319-322.

Singh P., Sumeriya, H.K., Sharma, V., Meena, R.K., 2007a. Response of various promising forage sorghum genotypes to different nitrogen levels. Research on Crops 8(2), 316-318.

Tanzubil Paul, B., 2014. Effect of variety and nitrogen fertilization on insect pest incidence in Sorghum in the Sudan Savanna of Ghana. Journal of Entomology and Zoology Studies 2(6), 12-15.

Tanzubil, P.B., Zakariah, M., Alem, A., 2006. Effect of nitrogen and farm yard manure on insect pests of pearl millet in northern Ghana. Tropical Science 44(1), 35-39.

Yusefzadeh, M., Daneshvar, M., Shahrvasv, S., Sorkhe, H., 2013. The effects of ethephon and nitrogen fertilizer on yield and yield components of sweet sorghum. Iranian Journal of Field Crop Science 44(2), 199-207. 